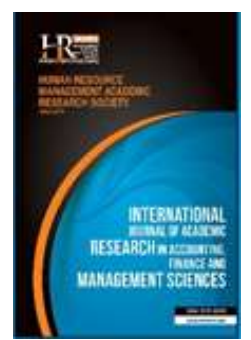

International Journal of Academic Research in Accounting, Finance and Management Sciences

Vol. 10, No.1, January 2020, pp. 55-70

E-ISSN: 2225-8329, P-ISSN: 2308-0337

(C) 2020 HRMARS

www.hrmars.com

To cite this article: Dad, A., Karim, A.M., Devi, R. (2020). Women Empowerment in the Textile Factories: Study on Punjab Province, Pakistan, International Journal of Academic Research in Accounting, Finance and Management Sciences 10 (1): $55-70$

http://dx.doi.org/10.6007/IJARAFMS/v10-i1/6992

(DOI: 10.6007/IJARAFMS/v10-i1/6992

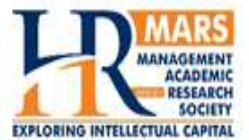

www.hrmars.com

ISSN: $2225-8329$

\title{
Women Empowerment in the Textile Factories: Study on Punjab Province, Pakistan
}

\author{
Allah Dad ${ }^{1}$, Asif Mahbub Karim², Rohini Devi ${ }^{3}$ \\ ${ }^{1}$ Assistant Professor, Pakistan Institute of Fashion and Design, \\ ${ }^{2}$ Dean, BGS, Binary University, Malaysia, ${ }^{2}$ E-mail: drasifmkarim@gmail.com (Corresponding author) \\ ${ }^{3}$ Deputy VC, Binary University, Malaysia
}

\begin{abstract}
The Textile Industry of Pakistan is considered as the lifeline of the country's economy. It accounts for the nearly 55\% share of the total economy. Major exports from textiles are yarns, raw and finished fabrics and also a limited quantity of value-added textile items. The role of employees always considered as key parameter in obtaining performance. But involvement of women on job place is very less in Pakistan textile industry. Only garment sector containing majorly women employment. The issues regarding their workplace is needed to be identified about their workplace satisfaction and finds out reason why women are not involved on job place in textile industry on large scale. In this research paper a survey will be conducted and concluded about issues of involvement on job place in two cluster region of textile factories i-e Lahore and Faisalabad.

Key words Women Empowerment, Textile Factory, Employment, Engendering Wages

Received: 08 Feb 2020 (C) The Authors 2020

Revised: 18 Feb $2020 \quad$ Published by Human Resource Management Academic Research Society (www.hrmars.com)

Accepted: 26 Feb 2020 This article is published under the Creative Commons Attribution (CC BY 4.0) license. Anyone may Published Online: 10 Mar 2020 reproduce, distribute, translate and create derivative works of this article (for both commercial and non-commercial purposes), subject to full attribution to the original publication and authors. The full terms of this license may be seen at: http://creativecommons.org/licences/by/4.0/legalcode
\end{abstract}

\section{Introduction}

The textile industry has a noteworthy position in the business arrangement of Pakistan, as it caters an important need of human beings, namely, clothing. The total worth of textile goods around the globe stood $\$ 667.5$ billion in 2015 in which about $83.1 \%$ were fabrics and $16.9 \%$ were yarns, higher $1.5 \%$ as compared to the previous year discussed in World Bank Report of 2016. Therefore it has been estimated that in the year 2020 the worldwide market worth of textile organization will be $\$ 842.6$ billion which is an enormous increase of $26.2 \%$ since 2015 (Sheng-Lu 2017). The composite yearly development amount of the market was $4.4 \%$ amongst 2011-15. Whereas the market place of Textile factories from Asia-Pacific Land considered for $54.6 \%$ of the worldwide worth in 2015 and Europe considered aimed at an additional $20.6 \%$ of the marketplace. The composite yearly growing amount of the market in the period $2015-20$ is projected to be $4.8 \%$. The demand to remain in textile business always been important due to expansion every year. Depletion of apparel is more income and price reactive than food, for instance, the Worldwide crosssectional investigation has shown apparel spending has an earnings springiness of about 0.9 while food has an earnings springiness of 0.1 to 0.3 in strong economic countries (Seale et al., 2003).

The textiles business might exactly name the flying buttress of Pakistan's economy for the subsequent 3 explanations. Primary, its retrograde connection with the agrarian segment in the form of raw material, the lifeline of Pakistan's economy. Second, yarns and fabric built-up are the main industrial 
entities in the country, book-keeping for the leading stake of an industrial asset, value-added products, and able to give more jobs. Third and utmost significant, these are high export concentration originalities. The Pakistani textile raw woven fabric manufacturing industry consists of three distinct sectors representing broadly three levels of technology and organization, namely high speed looms of the mill sector, power looms and handlooms. The handloom sector is time oldest among them with a long tradition of excellence and unrivalled craftsmanship. The next line considered as textile processing which ended up at garment section which is most value added sector where women involvement took place.

Freedom to work- by choice, in conditions of dignity, safety and fairness- is integral to human welfare. To guarantee that women have access to this right is an important end in itself. From an economic point of view, reducing the gender gap in labor force participation can significantly boost global GDP. The areas with the largest gender gaps will benefit heavily. Many developed countries will also see their average annual GDP growth, which is significant during times of almost zero economic growth. International Women's Day is a wonderful day to celebrate the achievements of women. Even better, this is a great day to assess how your company can further improve its efforts in this area.

When you empower women in the workplace you allow them to have more control over their lives. Things like training and sponsorship opportunities, equality programs and grants, and even opportunities for advancement in senior level positions, will allow for the development that is so necessary.

Thankfully, many companies already have policies in place to encourage women to succeed in the workplace in various ways. Here are some ways companies around the world are empowering their female employees. However in export oriented sector the role of women employment and empowerment is still not fully undertaken in sector of textile which needed to be explained and identified. There is need to know the issues facing by current women workers in textile manufacturing sector either belong to medium or large scale units. The opportunity of giving jobs to female is equal available in Pakistan but large amount of employment is captured by male workers. The overall ratio of female worker as employment is very low as compared male.

$\begin{array}{lccc}\begin{array}{l}\text { Pakistan: Economic Empowerment } \\ \text { Country }\end{array} & \begin{array}{c}\text { Female Legislators, } \\ \text { Senior officials and Managers } \\ \text { \%age of total }\end{array} & \begin{array}{c}\text { Female } \\ \text { Professional and estimated } \\ \text { Technical workers }\end{array} & \begin{array}{c}\text { Ratio of female } \\ \text { to male }\end{array} \\ \text { Pakistan } & 2 \% & 26 \% & 0.29\end{array}$

Source: Report 2010. Human Development, UNDP

\subsection{Objective of Study}

The Social and Gender Survey will be conducted in order to understand the current situation, needs and challenges faced by women regarding studying and working within the apparel and textile industry, as well as the challenges facing companies regarding the employment of women. The results of the survey will be utilized in the activities by Taskforce for Women Empowerment to promote female participation across the industry.

\section{Literature review}

\subsection{Women and Trade Union}

Although initial legislation on labor law regarding trade union activities provided full freedom of organization for their rights which is given in Factories act 1934 selection of Pakistan also in industrial relationship ordinance (IRO) collective bargaining-(1969) but afterwards due to repressive legislation by military rulers, their role and strength have diminished their role considerably. Official data available on Pakistan Statistical Year Book 2008 that shows that unions in the formal sector only represent 5\% of workers. As of 318 unions present in 1996 there are only 39 operative in 2005. Accordingly to secondary data out of registered trade unions the female members are less than $2 \%$ reported in Pakistan Statistical Year Book of 2008. Except for Faisalabad where power loom sector there are large scale mobilization of workers otherwise trade union activities are almost nonexistent and where present they are also all male. 
Female are not only disorganized but they are culturally discouraged from participating in any kind of collective mobilization. Discussions with industry stakeholders revealed that most of the small factory female workers have no knowledge of companies' code of conduct, the rights to unionize and collective bargaining.

\subsection{Engendering Wages}

Wages in the textile sector across the world reflect a clear gender-based wage gap. On average, men in the garment sector earn more than women. Gender has an important role in determining the level of skill or performance for performance and the level of pay in the majority of national textile industries. Even in garment units that are engaged to produce products for multinationals such as GAP, Levi Strauss, women are forced to work overtime and their wages are inadequate, well above the minimum wage is less. A study 10 showed that 95 percent of women have no appointment letter. Another study by (Edgar \& Myers, 2005) also reached the same figure of 95 percent of women with no written contract. Another study showed that 97 percent of women were hired on a temporary basis and 64 percent were getting less than the minimum wage, which has been fixed by the government at Rs 17000 . Employees who have no written contract face more job uncertainty in times of less demand. They are prone to periodically forced layoffs and short weeks. Women, on average, often earn $45-50 \%$ of male wages under fixed wage structures. Even the same task or procedure, depending on the operative woman or man, is paid more or less. Workers are paid by the number of pieces they produce, so a person's pay depends on how fast he is able to work, even when both genders are of the same piece level. In reality, women usually earn less than men because of their lower output, which the car provided to them. This is again due to the environment. A researcher recognizes that it is the female rather than the male workers who suffer the most due to their concentration in units where slice rates and other types of uncertain contracts are common. The vicious cycle of sick will begin with poor productivity and quality management in low-skill workers and small factories. This leads to excessive overtime as fewer pieces can be done in each hour and workers take time to work. Prolonged fatigue, illness and accidents occur. These contribute to lower productivity and higher levels of work, as piece rate workers are not paid to work and therefore higher levels of work affect their pay significantly.

\subsection{National Legal Legislations}

First and foremost is the effective enforcement of labor standards and laws. As already discussed, Pakistan has all the necessary laws to meet all the issues that weaken the law, which affects all. There should be effective enforcement mechanisms to ensure compliance with labor law, in particular the enrollment of women workers for the social security system for health, maternity, disability and wage retirement benefits. Emphasis should also be placed on the right of workers, especially women workers, to organize themselves so that they can take care of their problems. The second problem is the coverage of these legislations. It generally extends only to workers in some sub-sectors of the textile value chain and only in other cases to the formal sector. In general, informal sector workers, especially home-based workers, also exist outside most of the law. Issuance of identity cards for workers which has become law.

\subsection{Minimum Wages}

The minimum wage has recently been fixed for unskilled worker, with more than Rs.17000 for textile workers. However, the issues here are whether this is sufficient and how to ensure that most workers receive this salary. This is particularly true for the informal sector which includes small factories and homebased workers. Third, high wages alone are not enough to sustain a livelihood. There is a need to ensure a minimum norm of 250 workdays. It has been observed that this is found not only in the textile industry, but also in other sectors of the textile value chain for most workers. It starts with cotton sowing, which is a seasonal activity, ginning is again a seasonal activity covering only three months. Work in piece-rate contracts is highly volatile as it relies on orders that the factory owner can manage to receive. This trend not only deprives workers, especially women of the perpetual hood, but also excludes them from the social security network of labor laws. Since most labor laws do not apply to seasonal and short time contracts. 


\subsection{Welfare Fund or Social Security}

Researchers (Karin, 2004), emphasize better implementation of labor standards to protect workers from the harmful consequences of business intensification. After the abolition of quotas, many developed countries have resorted to non-tariff barriers, which are significantly social compliance issues, with Section 301 alone responsible for rejecting the consignment of exports to the US. Standards and codes of conduct are needed to improve the situation regarding corporate social responsibility issues in factories. Government and research institutes, industry associations and business networks should work together in this regard. Standard Social Focus. Focus Certification Verification Initiative/Area.

\subsection{Social Standards}

There are many national and international standards in the textile and clothing sector such as SA 8000. The SA 8000 is an international standard for improving working conditions worldwide. It is based on the principles of thirteen international human rights conventions, ten of which are conventions of the International Labor Organization (ILO), which have been approved by Pakistan. It is based on certain women's specific conventions, such as the "United Nations Convention to eliminate all forms of discrimination against women", and the ILO Convention 100 and 111 (Equal for male and female workers for work of equal value Remuneration; Discrimination) Section 6.3 of ISO 26000 is based on .7 (Discrimination and Vulnerable Group GRI (LA14), which measures the ratio of men's basic pay to women by employee category 16) Similarly, Fair Labor is also based on the standards of the association, which seeks to provide equal remuneration to men and women based on ILO convicts. The Clean Clothes Campaign (also based on ILO convent) contained gender-specific rights and there are clear clauses: Apart from maternity leave, there is a legal provision of gender-specific rights for women workers under these standards. All these standards not only come The ILO and UN conventions are approved by Pakistan, but most of these standards are mandatory for export in developed countries, then compliance with these standards is a neglected part of the process.

\section{Methodology of research}

Firstly, the survey was conducted to interview 75 women as potential trainees for the training institutes who were selected by Pakistan Readymade Garments Technical Training Institute (PRGTTI) and Pakistan Knitwear Training Institute (PKTI) from Lahore, Female Exclusive Training Institute (FETI) and Faisalabad Garment City Company (FGCC) from Faisalabad. Women who live near the training institutes were selected from Lahore and Faisalabad, and ranged in age from 15-46. 42 women out of 75 were single and 33 women were married.

\begin{tabular}{|c|c|c|c|c|}
\hline Training institutes & District & No. of single women & No. of married women & Total \\
\hline PRGTTI & Lahore & 18 & 13 & $\mathbf{3 1}$ \\
\hline PKTI & Lahore & 9 & 12 & $\mathbf{2 1}$ \\
\hline FETI & Faisalabad & 15 & 8 & $\mathbf{2 3}$ \\
\hline Total & & $\mathbf{4 2}$ & $\mathbf{3 3}$ & $\mathbf{7 5}$ \\
\hline
\end{tabular}

Secondly, the survey was conducted to interview 67 small, medium and large apparel and textile companies, registered by Pakistan Readymade Garments Manufactures \& Exporters Association (PRGMEA) and Pakistan Hosiery Manufacturers \& Exporters Association (PHMA) in Lahore, as well as companies located within FGCC and registered and non-registered companies by PHMA in Faisalabad. The definition of a company's size is taken from the State Bank of Pakistan, that is, small: fewer than 50 workers; medium: 51-250 workers; and large: more than 251 workers. The interviews were mainly conducted with Directors, CEOs and Managers in HR including other departments such as Marketing and Production of the targeted companies.

\begin{tabular}{|c|c|c|c|c|}
\hline Associations & District & No. of large companies & No. of small and medium companies & Total \\
\hline PRGMEA & Lahore & 19 & 11 & $\mathbf{3 0}$ \\
\hline PHMA & Lahore & 9 & 9 & 18 \\
\hline FGCC/PHMA/Others & Faisalabad & 10 & 9 & $\mathbf{1 9}$ \\
\hline Total & & $\mathbf{3 8}$ & $\mathbf{2 9}$ & $\mathbf{6 7}$ \\
\hline
\end{tabular}




\section{Results}

\subsection{Women's Relationships within the Apparel and Textile Sector}

$21.3 \%$ of the 75 surveyed women from Lahore and Faisalabad were family members, who are studying or have studied in apparel and clothing training institutes. 9.3\% of the women had family members and $4 \%$ of the women had friends who belong to apparel and clothing training institutes. $30.7 \%$ of the women had family members who are working or working in a company of apparel and textiles and $16 \%$ were friends of women, and $10.7 \%$ of women had extended family members belonging to the apparel and textile company. The women replied that their family members, relatives and friends work for textile factories. Some women replied that their family members own their boutique and work on sewing from home.

\subsection{Women Motivation for Textile Study}

In Lahore and Faisalabad, "tailoring" and "fashion designing" were the most preferred women's courses Fashion Designing Course. Apart from these two courses, pattern drafting and grading, CAD-CAM and quality control courses were also mentioned, but were less popular among women. These three courses are highly technical courses. All of the women who refer to these three courses have family members, relatives or friends who have either studied in a training institute or worked in a garment company. It is suggested that courses that are less popular among women should be promoted and advertised more to help raise awareness and encourage more participation.

\subsection{Challenges Faced by Women Wanting to Study}

Transport was the biggest challenge in Lahore and Faisalabad preventing women from benefiting from education and training. Distance was the second biggest challenge for women. $85.3 \%$ of women faced the challenge of transportation, while $76 \%$ of women faced distance. Many women replied that they could not afford the daily transportation costs. Many women replied that if transportation is provided by training institutes, this would encourage them to receive training. Regarding distance, the majority of women stated that it would be acceptable if the study took about 15 to 30 minutes, which suggests that women prefer to go from their homes to nearby training institutions. Nearly half of the women faced challenges such as not being able to afford school fees, concerns about safety and an inappropriate study environment. $57.3 \%$ women faced the challenge of school fees, $50.7 \%$ women mentioned safety issues, while $48 \%$ women highlighted the study environment as a challenge.

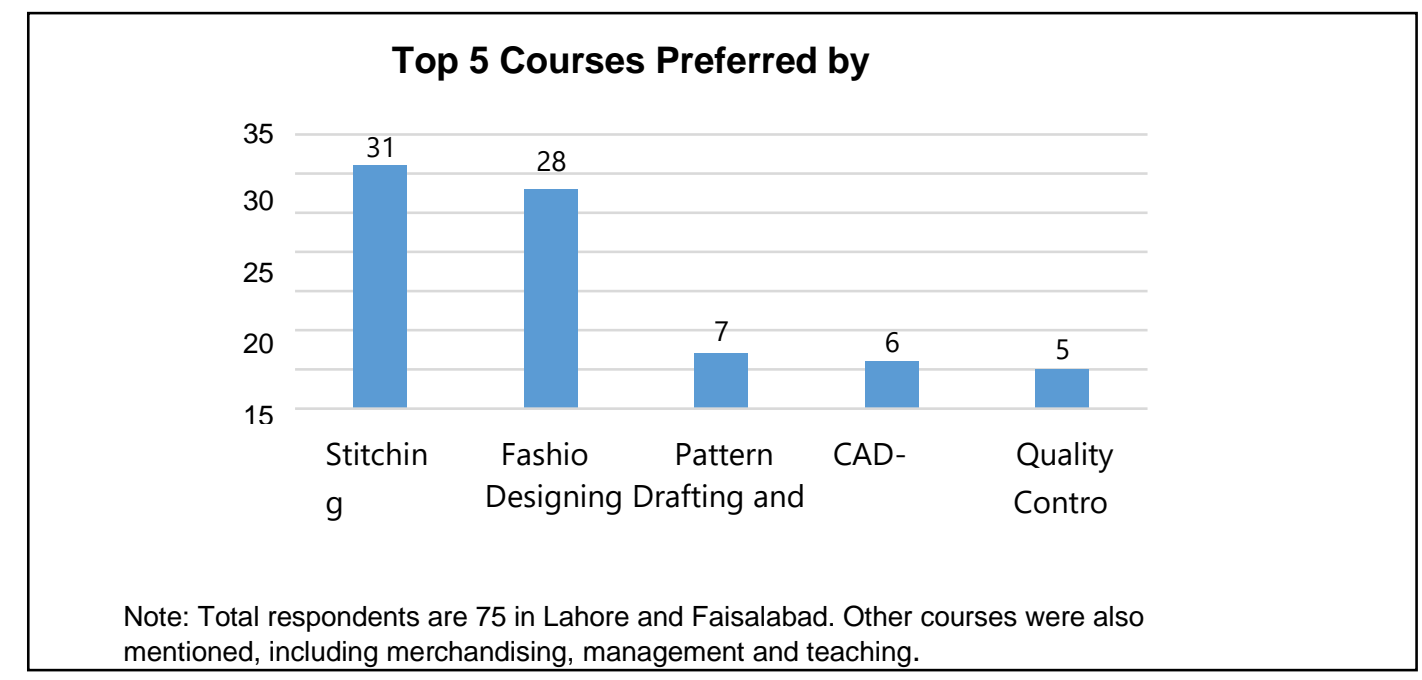



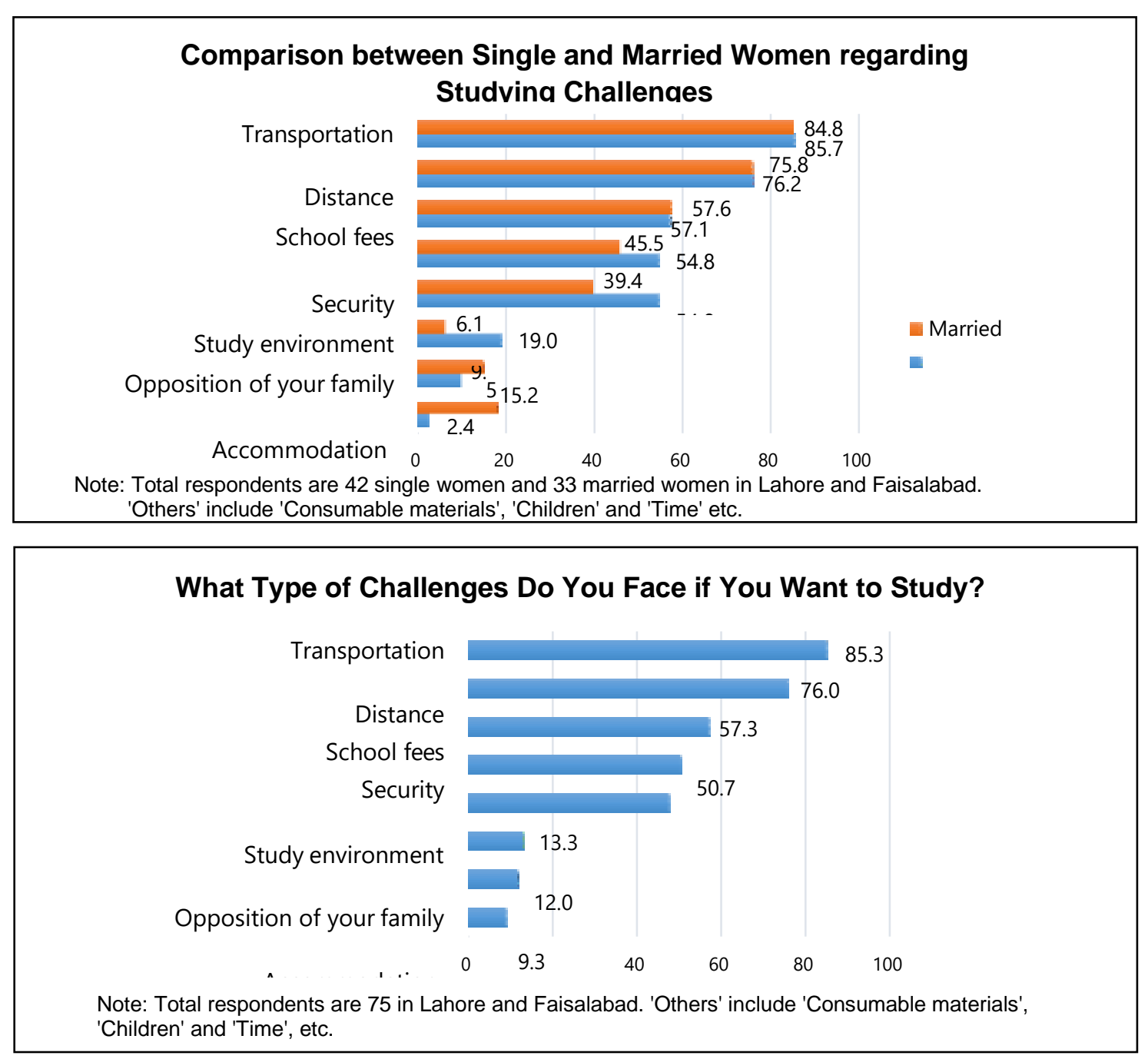

\subsection{Expectations of Women Regarding Studying}

Transport among women was the most expected provision when she studied. Free training was second. $86.7 \%$ of the women expected transportation and $74.7 \%$ of the women expected free training from a training institute.

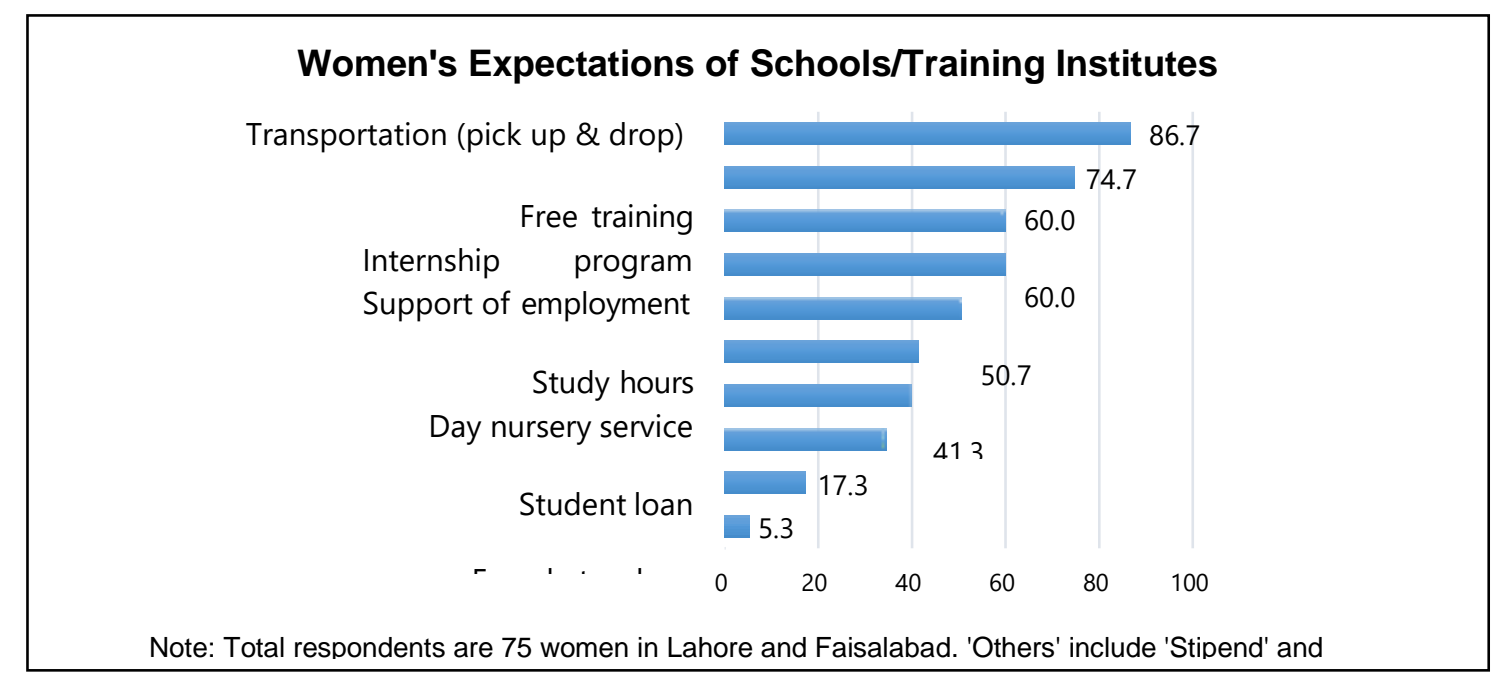

Many women have expected their own business as well as employment support to build a good relationship with the industry and gain a better job. Many women responded that they could feel more 
comfortable and relaxed if they received training from female instructors, while some responded that this is not the issue. Many women responded that they could not bear daily transportation costs and school fees, highlighting their economic needs. $60 \%$ of women expected support with internship programs and employment. $50.7 \%$ women expected appropriate study hours, $41.3 \%$ women nursed the day, and $40 \%$ women expected student loans. $34.7 \%$ women are expected to be taught by female teachers. Some women responded that they do not have any family members or relatives who can take care of their children and therefore need to use day nursery provision within training institutions.

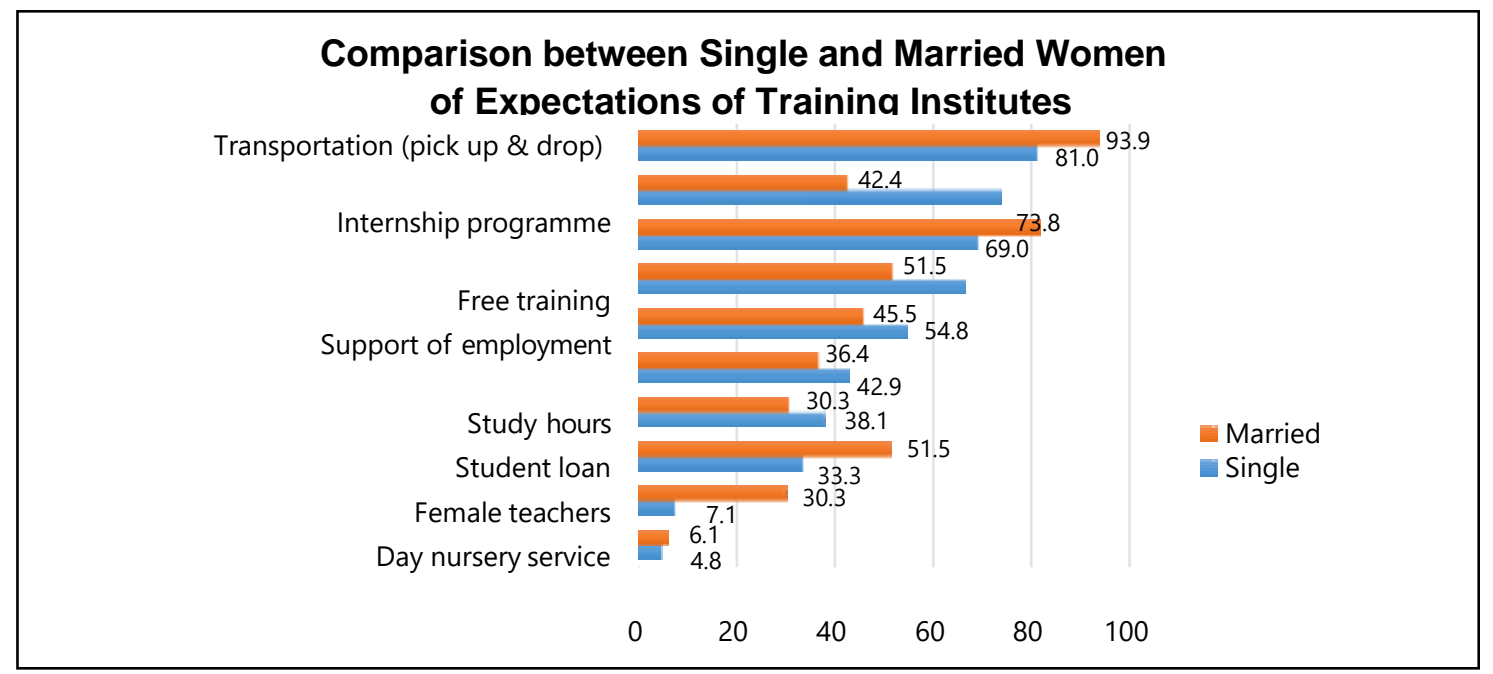

Compared to single and married women in Lahore and Faisalabad, the survey stated that single women expect more system support from training institutions, such as internships and counseling, while married women expect convenience and financial support. Compared to married women, single women were expected to have internships, assistance in finding employment, favorable study hours, student loans, and female teachers from training institutions. $73.8 \%$ of single women expected internship programs, while $42.4 \%$ of married women expected the same, showing a notable difference between groups. Some single women expected internship programs as they seek to develop connections within the industry for work. Many single women responded that if they received employment support from training institutes, it would be quite an incentive to access training. Many single women responded that they preferred to study for a short time, such as two to five hours, as they too needed to continue their household chores and support their families. Married women were expected to have transportation, free training, day nursery care, and housing compared to single women. $81.8 \%$ of married women expected free training, compared to $69.8 \%$ of single women. $51.5 \%$ of married women expected day nursery service, while $33.3 \%$ of single women expected it. Many married women said they expected housing allowance due to transportation, school fee subsidies and limited family budgets as they would have to spend money on their family. In addition, some married women replied that they would like to use the nursery service one day because they do not have any family members to care for their children. The results suggest that married women expect convenience and financial support from training institutions.

\subsection{Challenges for Women in Work}

Transport was the most common challenge faced by women in Lahore and Faisalabad when they worked. After that, long distances and working hours were a big challenge for women. $61.3 \%$ of the women faced the challenge of transportation, $56 \%$ of the women faced the distance challenge, and $54.7 \%$ of the women faced work hours as a challenge. Many women responded that they could not afford daily transportation costs, again highlighting economic needs. Some women responded that they are unable to work overtime due to the care of their children. $8 \%$ of women faced opposition from their families, much less compared to other challenges. As a result, the result suggests that reducing these challenges by providing basic facilities to accommodate women may result in more women being encouraged to participate in the industry. 


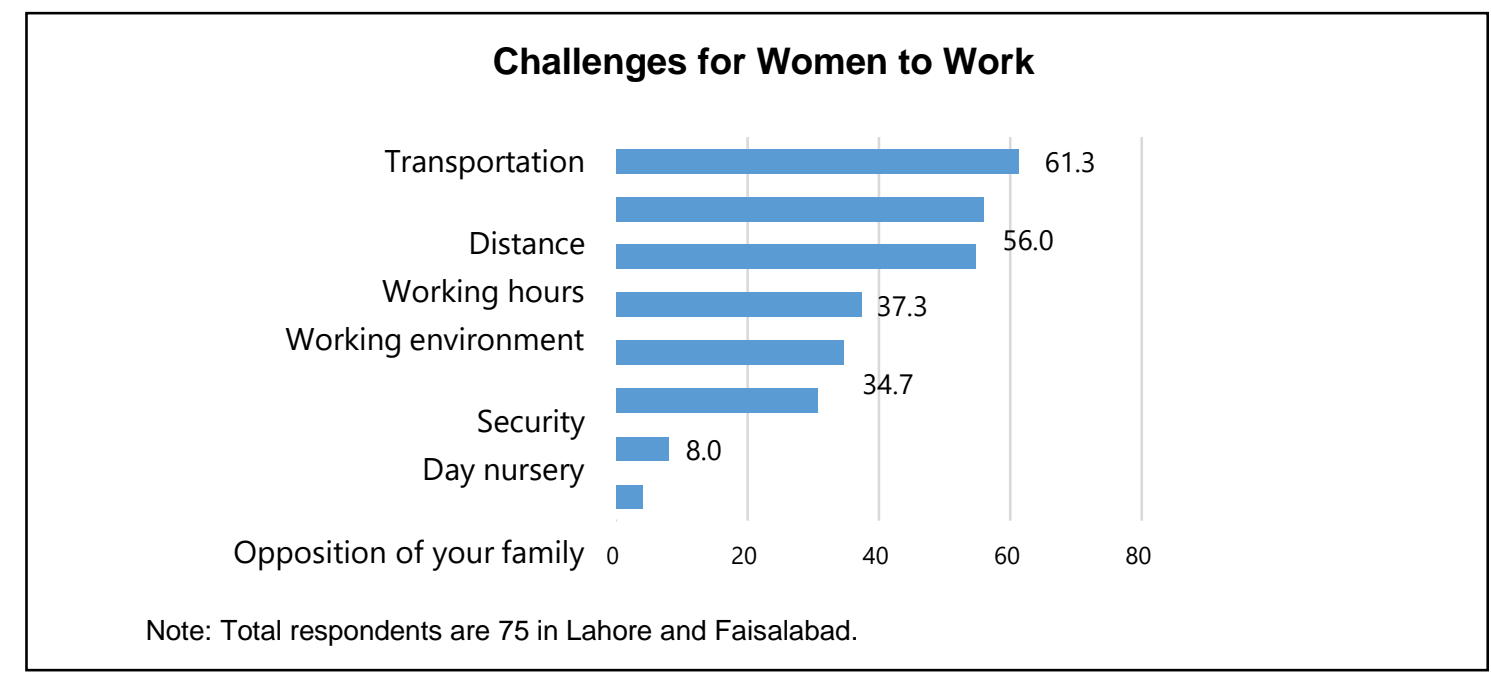

\subsection{Prospects of Women at Work}

Separate female toilets by women in Lahore and Faisalabad are most expected at the workplace, $76 \%$ of total women. $72 \%$ of women expected a prayer room for women, $62.7 \%$ of women expected transportation and $61.3 \%$ of women expected a separate work space for men. About $40 \%$ to $48 \%$ of women expected insurance, flexible working hours, training courses, and a female counselor. $29.3 \%$ of the women expected day nursery provision in the company. Most of the women responded that to maintain their dignity it is mandatory to have a separate toilet from men. Many women expressed that they needed to be able to pray in peace. Many women also expressed that they feel comfortable having a separate workplace from men.

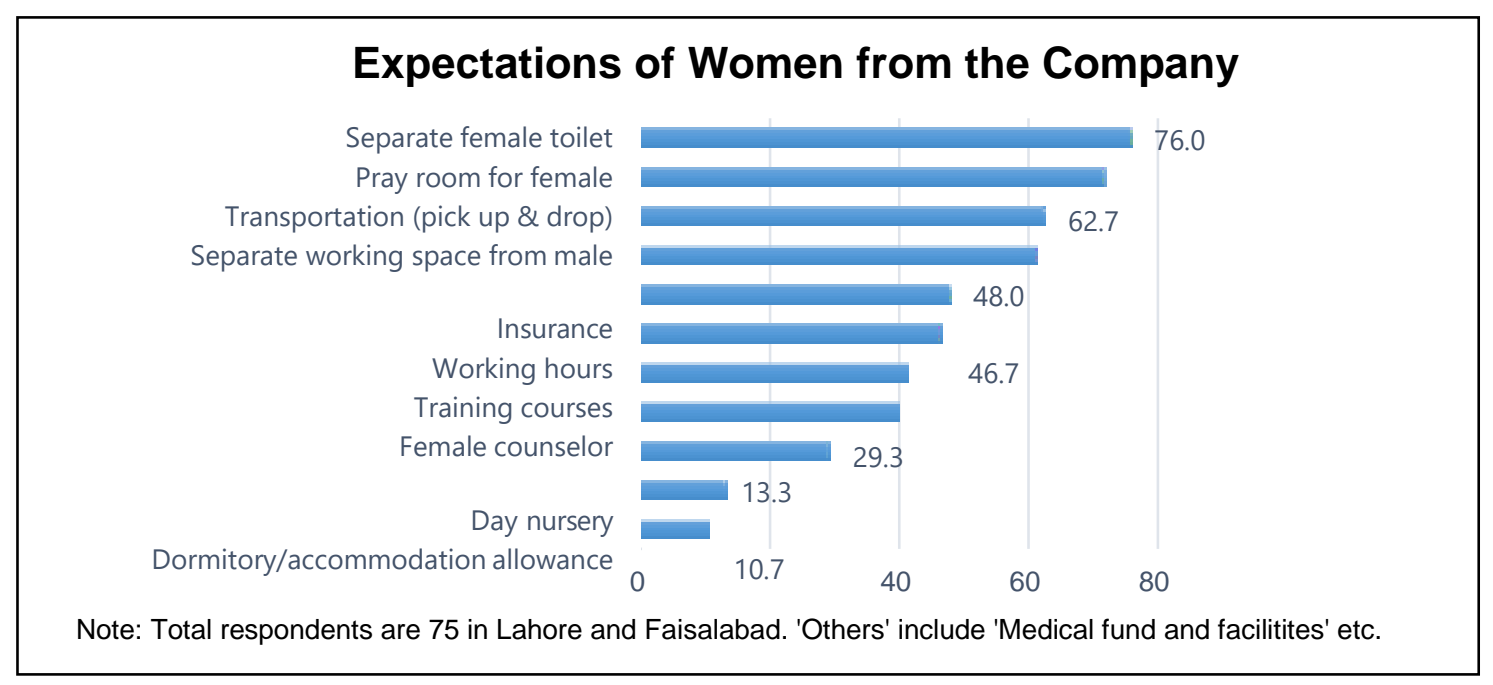

The ratio of female to male employees has been observed that the number of female employees in the surveyed companies in Lahore and Faisalabad was much lower than the number of male employees. In Lahore, only $15 \%$ of the workforce was women, while in Faisalabad it was $22 \%$

The percentage and percentage of female employees in large-sized companies shows the percentage in small and medium-sized companies in Lahore. The percentage of female employees in large companies in Lahore was $15 \%$, while it was $14 \%$ for small and medium-sized companies, illustrating a similar ratio. In contrast, in Faisalabad, the proportion of female employees in large companies was $22 \%$, while it was $10 \%$ for medium companies. This shows that the ratio of female employees in large companies in Faisalabad is almost double the size of medium companies in the same district. This can be attributed to the presence of a large company in Faisalabad which promotes female employment and has a large number of female employees. During the survey, it was observed that many companies showed a willingness to hire women in the future, even though their current proportion of female employees is low. Many medium-sized 
companies in Faisalabad said they would like to hire more women in the future. Some companies expressed that providing a suitable environment where women feel comfortable is not yet available and would like to improve the environment to be able to recruit more women in the future. One of the companies said that they recently hired a female HR manager to help recruit more women. The percentage of female employees in large companies in Faisalabad is larger than in Lahore, while the percentage of female employees in small and medium companies in Lahore is higher than the medium companies in Faisalabad.

\subsection{The Proportion of Female and Male Managers}

The proportion of women managers in large companies and medium companies in Lahore. The percentage of large firms in Lahore was $8 \%$, while $9 \%$ for small and medium a company, which shows just a small difference in the employment of women managers in Lahore. Statistics show that the percentage of female managers in large companies in Faisalabad was $12 \%$, while only $2 \%$ for medium companies, indicating that the proportion of large firms promoting women to management positions was six compared to medium firms in Faisalabad Times more. Percentage of female managers of the top 5 companies in Lahore and Faisalabad compared to the number of male managers. The company with the highest proportion of female managers was Company $A$ in Lahore with $46 \%$, while it was $33 \%$ for Company $A$ in Faisalabad. Lahore had three companies (B, $C$ and $D)$, with a range of women managers between $30 \%$ and $40 \%$, while only one company (B) in Faisalabad had the same limit. As shown in Figure 3-27, 3-29, the number of female managers within large companies in Faisalabad was higher than in Lahore. In contrast, compared to the top 5 companies between the two districts, the number of women managers of companies in Lahore was higher than in Faisalabad. This indicates that the number of companies promoting women managers in Lahore is likely to be higher than the number of companies in Faisalabad.

The company view 31 and 32 of the powers of women workers shows an idea of the strength of women employees in the garment/textile industry. Women employees were seen mainly by companies in both the districts based on their attitude and punctuality. It was observed that women in Faisalabad companies were more likely to stitch skills such as their strength, while companies in Lahore were more likely to see their attitude. 18 out of 48 companies in Lahore are considered to be the best strength, followed by 13 companies who appreciated the punctuality. Similarly, women were seen by 9 out of 19 companies in Faisalabad based on their attitudes and punctuality. In Faisalabad, 7 out of 19 companies stitched women's skills such as their strengths, while 3 out of 48 companies saw this in Lahore.

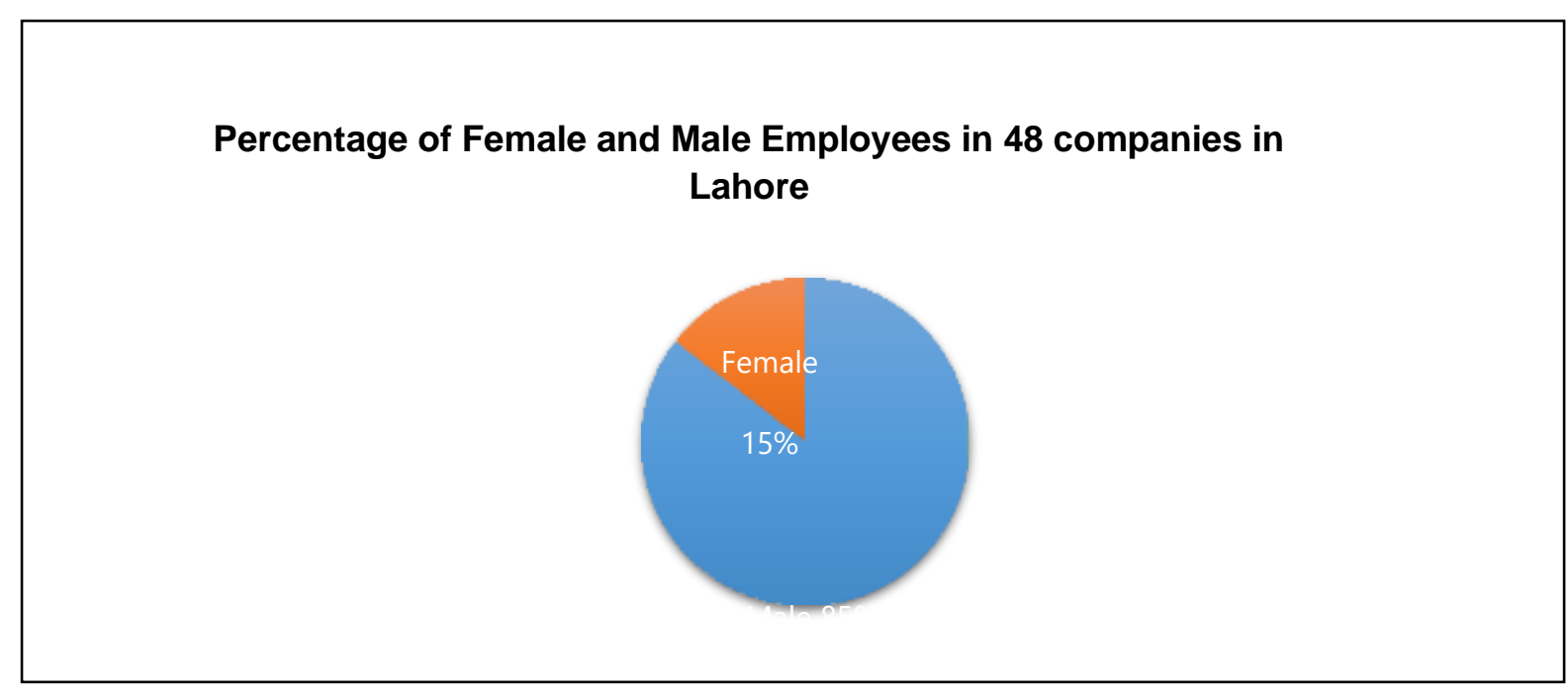

The number of female employees in the top five companies which employ the most females in Lahore and Faisalabad. Three companies had more female employees than males. Two of those three companies in Lahore employed $89 \%$ and $82 \%$ women, respectively, which is a very high proportion. $57 \%$ of the workforce from the other company in Faisalabad was female. 


\section{Percentage of Female and Male Employees in Large Sized Companies in Faisalabad}

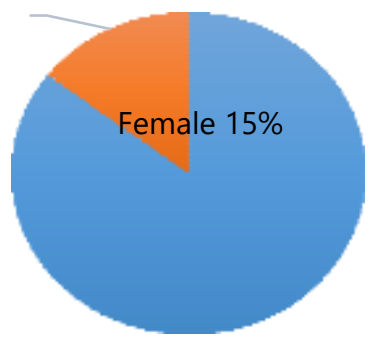

\begin{tabular}{|c|c|c|c|c|c|}
\hline Company & District & $\begin{array}{c}\text { Size of } \\
\text { company }\end{array}$ & $\begin{array}{c}\text { No. of female } \\
\text { employees }\end{array}$ & $\begin{array}{c}\text { No. of male } \\
\text { employees }\end{array}$ & $\begin{array}{c}\% \text { of female } \\
\text { employees }\end{array}$ \\
\hline Company A & \multirow{5}{*}{ Lahore } & Large & 780 & 100 & $89 \%$ \\
\hline Company B & & Large & 993 & 218 & $82 \%$ \\
\hline Company C & & Large & 1600 & 2400 & $40 \%$ \\
\hline Company D & & Medium & 150 & 250 & $37 \%$ \\
\hline Company E & & Medium & 30 & 50 & $37 \%$ \\
\hline Company A & \multirow{5}{*}{ Faisalabad } & Large & 200 & 150 & $57 \%$ \\
\hline Company B & & Medium & 25 & 40 & $38 \%$ \\
\hline Company C & & Large & 6500 & 13500 & $32 \%$ \\
\hline Company D & & Large & 1642 & 6568 & $20 \%$ \\
\hline Company E & & Medium & 20 & 80 & $20 \%$ \\
\hline
\end{tabular}

The percentage of female managers from the top 5 companies in Lahore and Faisalabad compared to the number of male managers. The company with the highest proportion of female managers was Company $A$ in Lahore with $46 \%$, while it was $33 \%$ for Company $A$ in Faisalabad. Lahore had three companies ( $B, C$ and $D$ ), with a range of women managers between $30 \%$ and $40 \%$, while only one company (B) in Faisalabad had the same limit. As shown above in the picture, the number of female managers within large companies in Faisalabad was higher than in Lahore. In contrast, compared to the top 5 companies between the two districts, the number of women managers of companies in Lahore was higher than in Faisalabad. This indicates that the number of companies promoting women managers in Lahore is likely to be higher than the number of companies in Faisalabad.

Percentage of Female Managers in Surveyed Companies in Lahore and Faisalabad in Comparison with Male Managers (Top 5)

\begin{tabular}{|c|c|c|c|c|c|}
\hline Company & District & $\begin{array}{c}\text { Size of } \\
\text { company }\end{array}$ & $\begin{array}{c}\text { No. of female } \\
\text { managers }\end{array}$ & $\begin{array}{c}\text { No of male } \\
\text { managers }\end{array}$ & $\begin{array}{c}\% \text { of female } \\
\text { managers }\end{array}$ \\
\hline Company A & \multirow{5}{*}{ Lahore } & Large & 6 & 7 & $46 \%$ \\
\hline Company B & & Large & 17 & 30 & $36 \%$ \\
\hline Company C & & Large & 3 & 6 & $33 \%$ \\
\hline Company D & & Large & 11 & 25 & $31 \%$ \\
\hline Company E & & Medium & 2 & 6 & $25 \%$ \\
\hline Company A & \multirow{5}{*}{ Faisalabad } & Large & 5 & 10 & $33 \%$ \\
\hline Company B & & Large & 5 & 18 & $22 \%$ \\
\hline Company C & & Large & 3 & 11 & $21 \%$ \\
\hline Company D & & Large & 2 & 10 & $17 \%$ \\
\hline Company E & & Large & 50 & 300 & $14 \%$ \\
\hline
\end{tabular}


Company View of Female Workers' Strengths

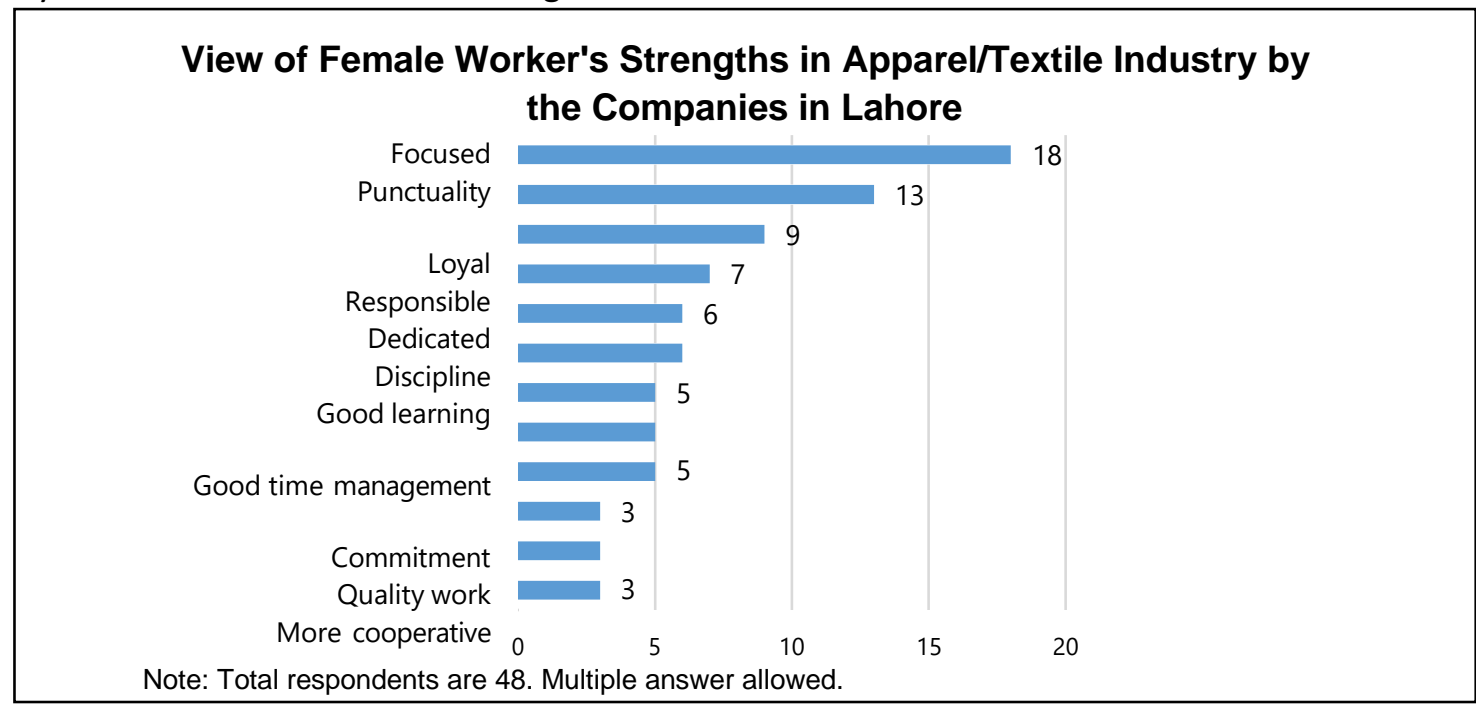

Top In-Demand Section and Company Plan for Female Employment

\section{View of Female Workers' Strengths in Apparel/Textile Industry by the Companies in Faisalabad}

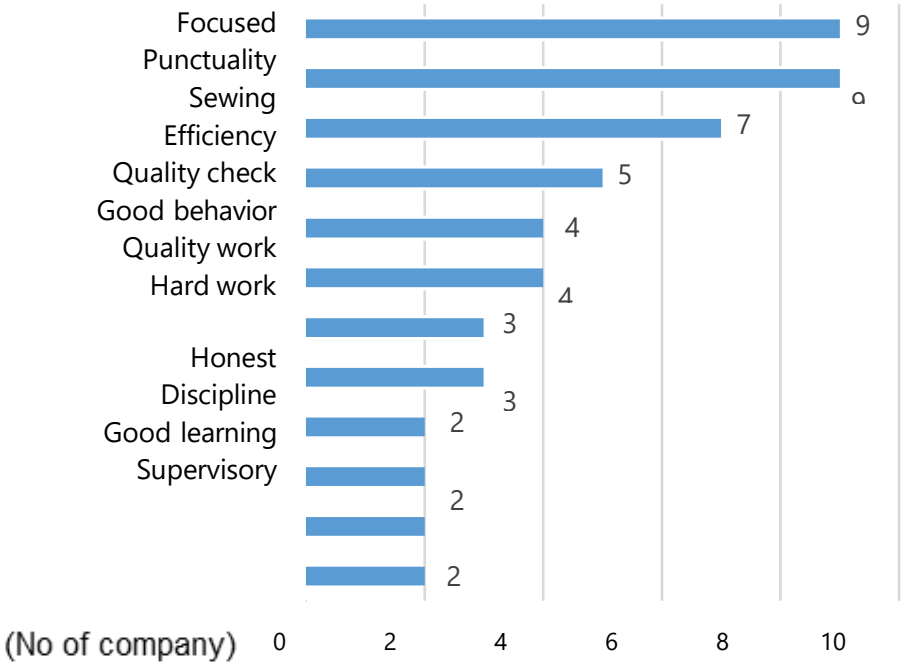

Note: Total respondents are 19. Multiple answer allowed.

Answers from companies in Lahore and Faisalabad regarding the lag of hiring female employees. The most common response from companies in both districts regarding the gaps in hiring female employees is that they are less likely to face female applicants/employees due to issues of culture norms, skills shortages and work time restrictions. Companies in Lahore also faced environmental and geographical issues, as well as a lack of training institutes in their area. Conversely, companies in Faisalabad were likely to highlight heavy workload as an issue. There were also several companies in the two districts that responded that they had no problem in hiring female employees. 


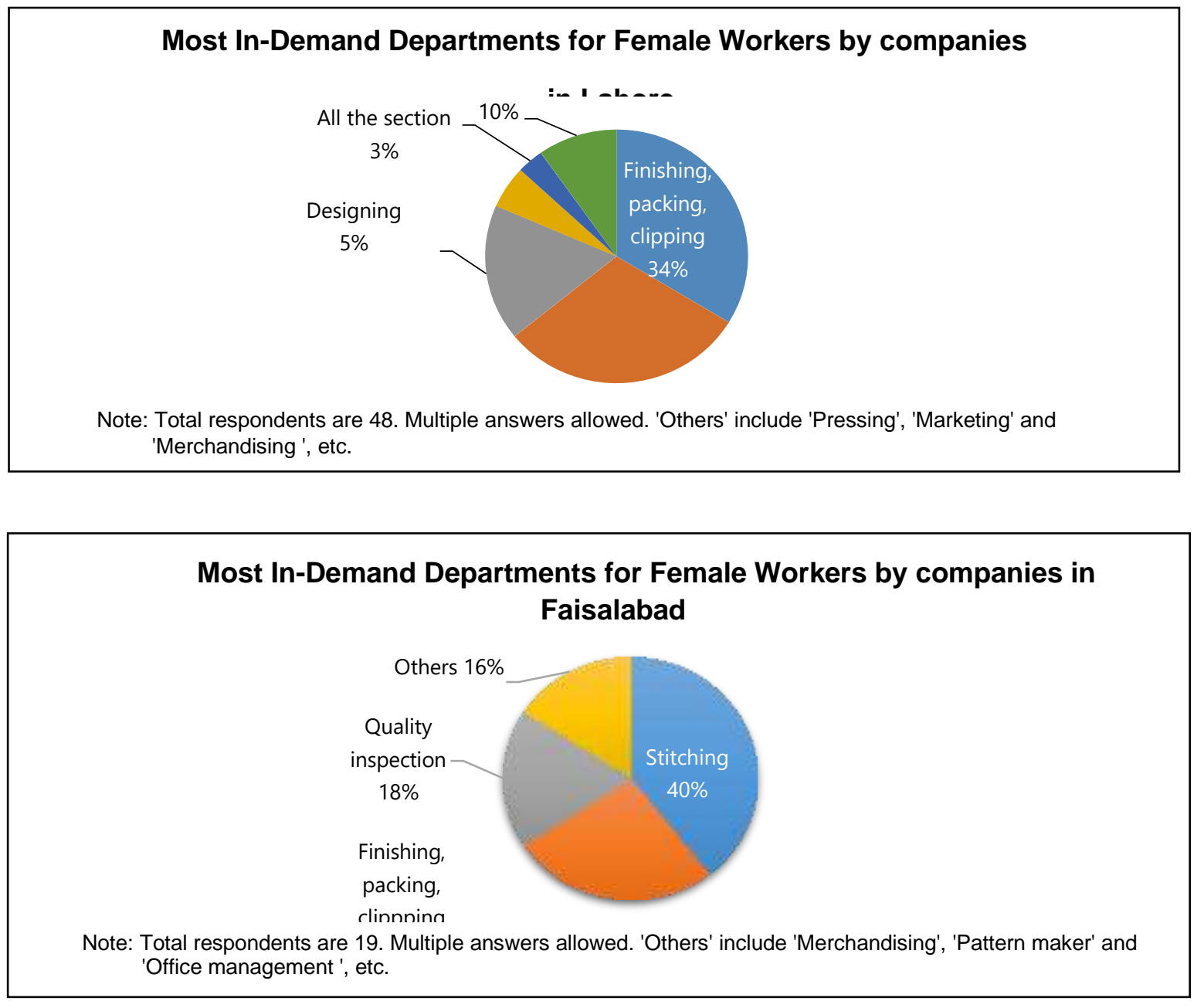

Gap in Hiring Female Employment in 52 Companies in Lahore and Faisalabad

\begin{tabular}{|c|c|c|}
\hline $\begin{array}{l}\text { Common answers in } \\
\text { Lahore and Faisalabad }\end{array}$ & District & $\begin{array}{c}\text { Major answers } \\
\text { (No. of respondents) }\end{array}$ \\
\hline \multirow[t]{2}{*}{$\begin{array}{l}\text { - Fewer female applicants } \\
\text { /employees due to culture norms } \\
\text { - Lack of skilled force } \\
\text { - Working time constraints } \\
\text { - No gaps }\end{array}$} & Lahore & $\begin{array}{l}\text { Fewer female applicants (some companies explained the } \\
\text { reasons as culture norms) (8) } \\
\text { Lack of skilled force (6) } \\
\text { Lack of training institutions near companies (3) } \\
\text { Working time constraints (3) } \\
\text { Lack of qualifications (2) } \\
\text { Environment (2) } \\
\text { Geographic issue (2) } \\
\text { No gaps (2) }\end{array}$ \\
\hline & Faisalabad & $\begin{array}{l}\text { - Lack of skilled force (8) } \\
\text { Fewer female employees due to culture norms (4) } \\
\text { Heavy work load (2) } \\
\text { Working time constraints (2) } \\
\text { - No gaps (8) }\end{array}$ \\
\hline
\end{tabular}

Company Constraints to Hire Female Employee in Lahore and Faisalabad

\begin{tabular}{|l|l|l|}
\hline $\begin{array}{c}\text { Common answers in } \\
\text { Lahore and Faisalabad }\end{array}$ & District & $\begin{array}{c}\text { Major answers } \\
\text { (No. of respondents) }\end{array}$ \\
\hline $\begin{array}{l}\text { Fewer female applicant due to } \\
\text { culture norm }\end{array}$ & Lahore & $\begin{array}{l}\text { - Lack of skilled force (4) } \\
\text { - Fewer female applicants due to culture norms (2) }\end{array}$ \\
\hline
\end{tabular}




\begin{tabular}{|c|c|c|}
\hline \multirow[t]{2}{*}{ - No constraints } & & - No constraints (18) \\
\hline & Faisalabad & $\begin{array}{l}\text { - Fewer female applicants due to culture norms (4) } \\
\text { - Working time constraints (3) } \\
\text { - Pick and drop (2) } \\
\text { - Day care centres (2) } \\
\text { - No constraints (3) }\end{array}$ \\
\hline
\end{tabular}

Company Challenges regarding Current Female Employment in Lahore and Faisalabad

\begin{tabular}{|c|c|}
\hline District & Main answers (No. of respondents) \\
\hline Lahore & $\begin{array}{l}\cdot \text { Working time constraint }(3) \\
\cdot \text { Pick \& Drop (2) } \\
\cdot \text { Maternity leave (2) } \\
\cdot \text { Harassment }(2) \\
\cdot \text { No challenges }(12)\end{array}$ \\
\hline Faisalabad & $\begin{array}{l}\cdot \text { Turn over after marriage (3) } \\
\cdot \text { Co work environment (Negative impact) ( } 2 \text { ) } \\
\cdot \text { No challenges ( } 8 \text { ) }\end{array}$ \\
\hline
\end{tabular}

Comparison between Large-sized and Small \& Medium-sized Companies Providing Benefits for Female Employees in Lahore

\section{Comparison between Large-sized and Small \& Medium-sized Companies Providing Benefits for Female Employees}

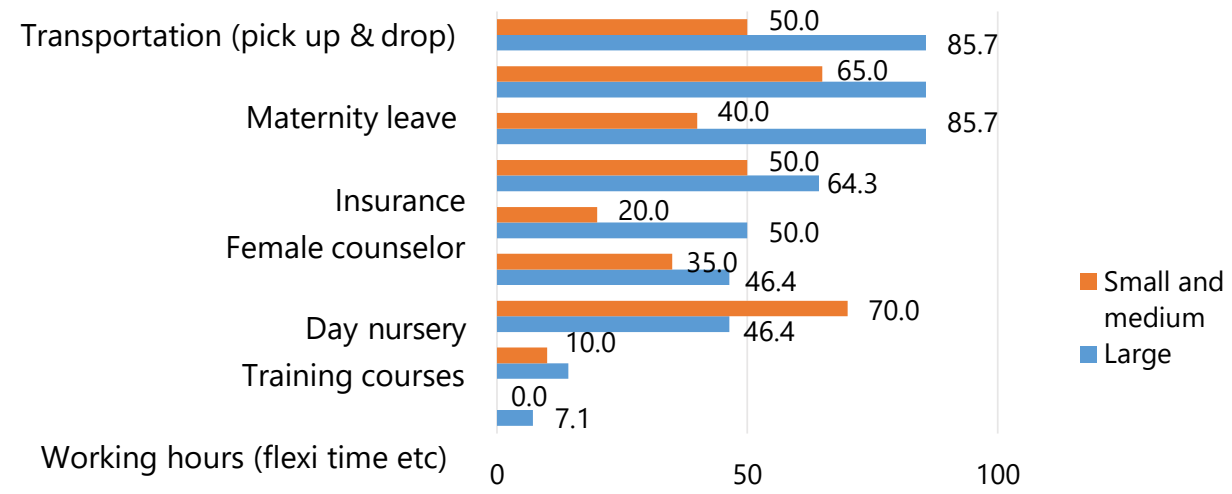

Note: Total respondents are 28 large companies and 20 small and medium companies in Lahore.

Comparison between Large-sized and Medium-sized Companies Providing Benefits for Female Employees in Faisalabad

\section{Comparison between Large-sized and Medium-sized Companies Providing Benefits for Female Employees}

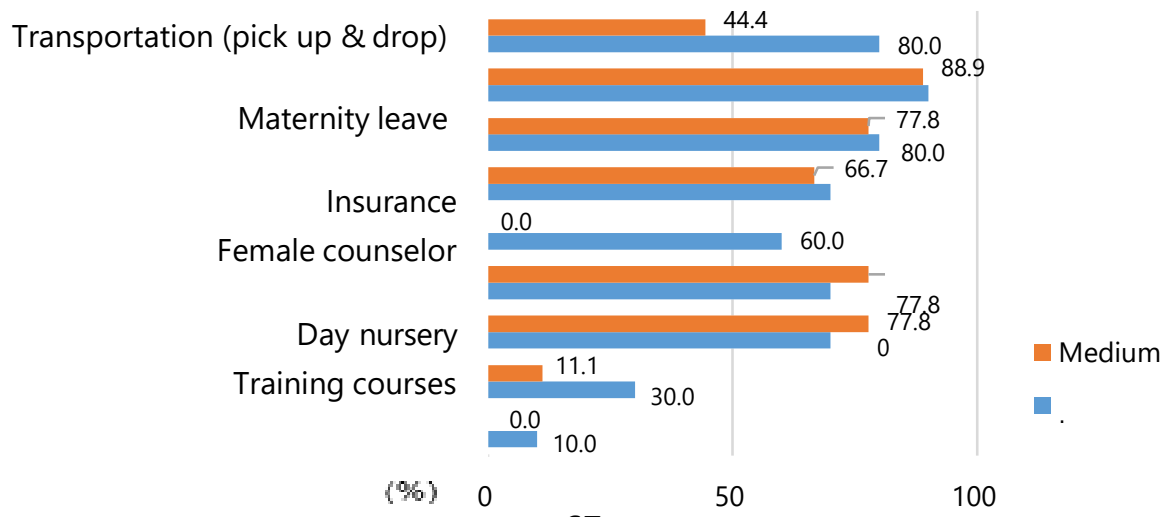

Note: Total respondents are 10 large companies an`马ु medium companies. Multiple answer allowed. 


\section{Comparison of Female-friendly Facilities Provided}

\section{by Large-scale and Small \& Medium-scale businesses in Lahore}

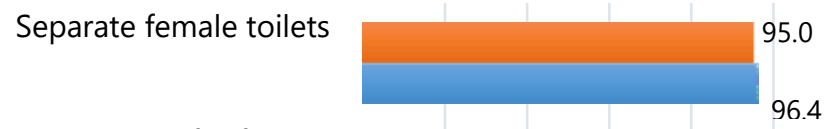

Prayer room for female

80.0

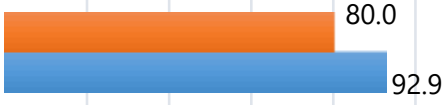

Separate working space from male

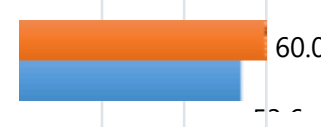

Small and medium

Others

1.0

(\%)

17.9

Large

$\begin{array}{llllll}0 & 20 & 40 & 60 & 80 & 100\end{array}$

Note: Total respondents are 28 large companies and 20 small and medium companies.

Multinle answers allowed 'Others' inclı ıde 'Female s.nmmnn rnom' 'Restrnnm' and 'Canteen'

Percentage of women left job due to bullying from Faisalabad and Lahore industry

\section{Comparison of Female-friendly Facilities provided \\ by Large-scale and Medium-scale businesses in Faisalabad}

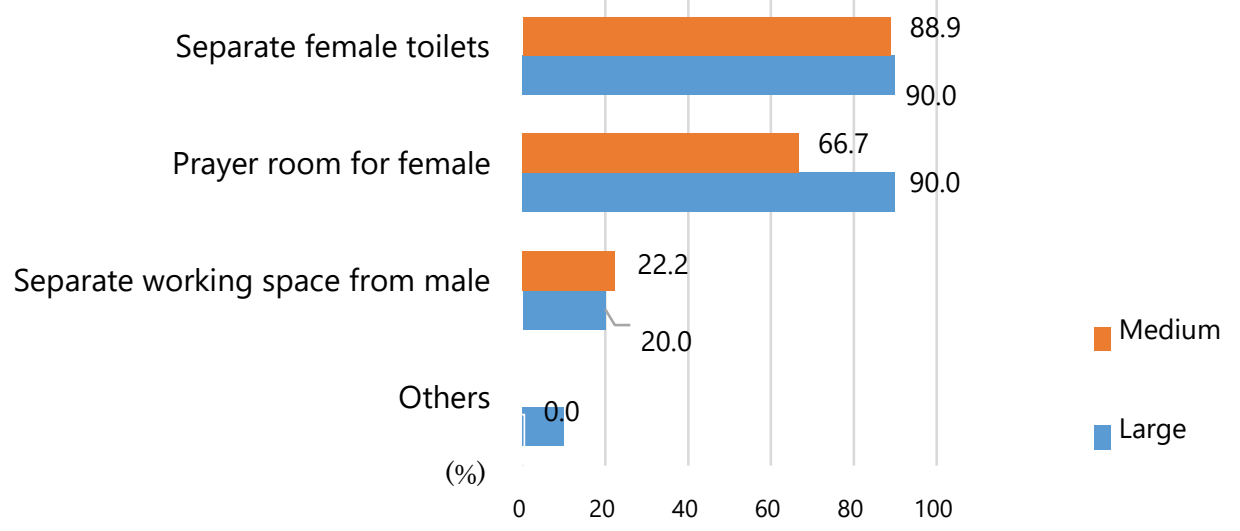

Note: Total respondents are 10 large companies and 9 medium companies.

Multiple answers allowed. 'Others' include 'Female common room,' 'Change room' and 'Canteen'. 


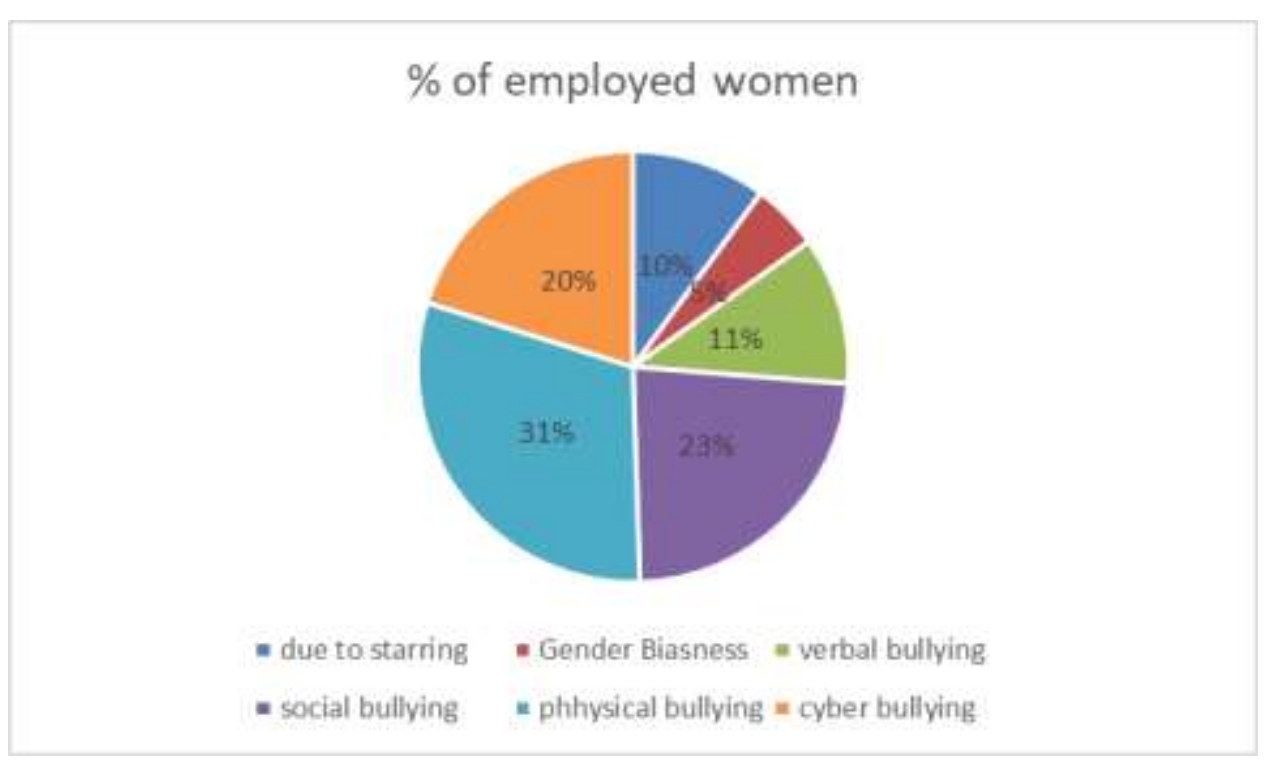

\section{Conclusions}

Pakistan's composition has distinct requirements for labor privileges, some of which are gender explicit.

The current regulations are not that abundant inadequate but poor/weak execution and implementation of the commandments mark them frail. The economic consequences of the agreements of textile and clothing for Pakistan were more or less as forecast. In more or less areas as probable the Pakistani textile industry ended well as a worldwide contractor in cotton yarns and fabrics. But else its under-investment in technology, in human resource enlargement and the deficiency of product expansion and recently energy crises and non-conducive environs due to law and order situation and radicalism donated to pessimistic it from competitiveness. In modifying these contests of new era of globalization the area that was entirely overlooked is the separate gender element of the textiles and clothing fabrication which can brand or breakdown the whole value of this sector. There is a need to expand the teaching program all through the textile and garment value chain parts so that further and more women could be able to get job chances. However, foremost emphasis should continuously be on garment sector. Combined training programs for women should be presented in the main textile cities. There should be appropriate syllabus growth over and done with affiliation with recognized institutions for safe guarding requirements of the garment industry. And finally there should be Proper harmonization among all the stake holders particularly the Donors, INGOs /NGO's, business connotations and government/s for authorizing women through skill development. The above findings of the paper not only contributes in industrial sector, it also equally contributes in academic field in order to find out relevant variables for knowing the role of women in textile sector also able to capitalize the framework of variables that helps to access the amount of empowerment given to women in underdeveloped countries. The Findings of the paper also contributes by contextualizing into specific field that is textile garment sector for knowing role and work place issues of women in above mentioned sector.

\section{Acknowledgement}

The authors would acknowledge the guidance of Global Academics Research Academy (GARA) for journal selection. Moreover, we are grateful to Onism Consultancy for editing and proofreading services. 


\section{References}

1. World Bank. (2016). World Bank, Gherzi analysis and $T T$ market model. Final Report 2016.Retrieved from: https://ec.europa.eu/growth/content/country-reports-technical-textiles-braziljapan-south-korea-and-usa_en

2. Edgar, R. C., \& Myers, E. W. (2005). PILER: identification and classification of genomic repeats. Bioinformatics, 21(suppl_1), i152-i158.

3. ILO. (2020). International Labor Organization Convention Report. Retrieved from: https://www.ilo.org/dyn/normlex/en/f?p=NORMLEXPUB:14002:0::NO:

4. Kurz, K. (2004). Labour market position, intergenerational transfers and home-ownership: a longitudinal analysis for West German birth cohorts. European Sociological Review, 20(2), 141-159.

5. Lu, S. (2017). Why is the Utilization of US Free Trade Agreements Falling for Apparel Imports?. International Textile And Apparel Association (Itaa) Annual Conference Proceedings. Retrieved from: https://pdfs.semanticscholar.org/edef/1e2c2b29441169e55c73b1a4185a66e5ad2b.pdf

6. Pakistan Statistical Year Book. (2008). Retrieved from: http://www.pbs.gov.pk/content/pakistanstatistical-year-book-2008

7. Seale, C. (2003). Media and health. Sage.

8. UNDP Human Development Report. (2010). The Real Wealth of Nations: Pathways to Human Development. Retrieved from: http://hdr.undp.org/sites/default/files/reports/270/hdr_2010_en_ complete_reprint.pdf

9. World Trade Organization. (2017). World Trade Statistical Review 2017. Retrieved from https://www.wto.org/english/res_e/statis_e/wts2017_e/wts17_toc_e.htm 